\title{
Evaluation of the transformation potential of urbanised landscape (Vilnius case)
}

\author{
Dalia Dijokienė, Vilnius Gediminas Technical University, Lithuania
}

\begin{abstract}
The article analyzes the evaluation of the transformation potential of valuable urbanised landscape. Many of the old towns formed as valuable urbanised landscapes. However, the transformation of urban structures of viable cities, which also entails transformation of urbanised landscapes, is inevitable. Basically, there are only two ways of transformation - either it happens in its own way or it can be professionally controlled. In this article the problem of urbanised landscape transformation is illustrated by the analytical work carried out for the eastern part of the Old Town of Vilnius (UNESCO heritage site). In the eastern part of the Old Town of Vilnius there are two architectural ensembles that form the characteristic panoramas and silhouettes of the Old Town. In this part of the city, various new built-up initiatives have been active since 2007. The article discusses the urban research, the purpose of which was to answer the question about the potential height of the newly designed builtup in a former historic suburb of Vilnius. The potential impact of new buildings on the panoramas, silhouettes, dominant elements, and perspectives as well as nominal spaces of that concrete street of the historical suburb is assessed based on the analysis of the townscape seen from typical external and internal viewing points of the Old Town. The article describes an integrated method of assessing visual effect on the urbanised landscape.

Keywords: urbanised landscape; townscape; panorama; silhouette; nominal space
\end{abstract}

Introduction

As a rule, towns have been developed in expressive natural settings and this has resulted in the creation of different urbanised landscapes geosystems composed of natural and sociogenic elements. Urbanised landscapes have shaped exceptional, unique, and recognisable townscapes. The panoramas and silhouettes of the majority of old towns are recognised as valuable heritage that needs to be preserved. However, the age of globalisation poses new challenges to the preservation of valuable urbanised landscapes. Nowadays the question raised is whether and to what extent urbanised landscape can transform to still remain recognisable and valuable.

International documents of the beginning of the 21 st century dealing with cultural heritage protection attribute equal significance to both contemporary and historical architecture. Contemporary architecture is subject to the following requirements: respect for historical context, harmony, and quality. In this article the problem of urbanised landscape transformation is illustrated by the analytical work carried out for the eastern part of the Old Town of Vilnius (UNESCO heritage site). Vilnius Old Town does not have a complete composition structure. On the contrary, it is an open structure at a certain stage of its development and only some of its microstructures are fully developed. Therefore, the composition and functional structure of the Old Town need to be developed further. This creates objective grounds for new architecture to appear in the Old Town. On the other hand, the built-up that has been developed in the Old Town of Vilnius is considered to be a historical and highly valuable environment, thus the height of the built-up is treated as final and the townscape that it creates is viewed as valuable. The objective of the analysis was to answer the question what height of new builtup is acceptable in this former historical suburb of Vilnius. The potential impact of new buildings on the panoramas, silhouettes, dominant elements, and perspectives as well as nominal spaces of that concrete street of the historical suburb is assessed based on the analysis of the townscape seen from typical external and internal viewing points of the Old Town. The article describes an integrated method of assessing visual effect on the urbanised landscape.

\section{Principles for creating new architecture in the historical environment}

Transformation of urban structures of viable cities, which entails transformation of urbanised landscapes, is inevitable. Basically, there are only two ways of transformation - either it happens in its own way or it can be professionally controlled.

At the beginning of the article, we will briefly discuss according to what principles, what and where might emerge in a historically established, urbanistically valuable territory. The protection of cultural heritage worldwide is governed by charters, conventions, declarations and recommendations of various heritage protection organizations. It is often that they complement one another, however some common trends can be felt. The documents of the Council of Europe, UNESCO and ICOMOS international organizations contain provisions not 
only on the protection of cultural heritage, but also on development of new architecture in the historical environment, which, incidentally, has kept pace with the flow of time. Brief overview of these provisions:

- The 7 th -8 th decades of the 20th century. The context of cultural heritage was treated as a basis for creativity, also the structural and compositional harmony of new structures with the historical environment was encouraged and there was an emphasis on the principle of modernity - each piece must represent its age.

- The 8th - 9th decades of the 20th century. Knowing and respecting the context of cultural heritage should lead to the organic relationship of a new piece with the environment. Emphasis is placed on maintaining the integrity, identity and local spirit of the historical environment. When developing new architecture, it is recommended to use building materials typical of the region and to preserve traditional technologies. New architectural works should complement and enrich the values of historical media without transforming them. The principle of modernity is emphasized more gently - the novelty of an object should be recognized only by carefully examining it.

- The juncture of the 20th - 21st centuries. International documents support the transformation of historical urban environment, preserving and strengthening the cultural significance and specific character of the heritage. The latest documents attempt to combine both the provisions for protection and sustainable consumption and the provisions for development and creation of new architecture. The promotion of contextual, contemporary and high-quality architecture is encouraged. A new piece of architecture should reflect its age and traces of intervention should be recognized in the future.

International documents of the beginning of the 21 st century treat contemporary architecture as equivalent to historical architecture - "Historic and contemporary architecture constitute an asset to local communities" [1]. Requirements for modern architecture are respect for the historical context, harmony and quality. Provisions that could be referred to in creation of new objects in valuable urban areas are also described in the Management Guidelines for World Cultural Heritage Sites prepared on the joint initiative of ICCROM and ICOMOS under the auspices of UNESCO. Designed new modern structures should express the spirit of their times, but also take into account the historical context. The design of new structures should be based on a clear systematic analysis of the morphology of the historical fabric. According to the Guidelines, the new building should have:
- a rhythm that harmonizes with the urban rhythms and the morphological pattern of the surrounding fabric;

- a mass in balance in its context (...);

- a street boundary line following the line of the existing setbacks;

- a silhouette respecting the traditional local character and silhouette;

- materials that are traditional, or compatible with traditional materials;

- windows similar in character and in window:wall ratio to typical buildings in the same area;

- and be of high quality in construction and design... [2].

V. Jurkštas, one of the most famous researchers in the old towns of Lithuania, who studied in detail the volumetric spatial composition of the Vilnius Old Town, drew attention to the fact that the most striking feature of the urban structure of the Vilnius Old Town is the diversity of spatial composition. He also said that: "[Vilnius] Old Town does not have a complete composition structure. On the contrary, it is an open structure at a certain stage of its development and only some of its isolated microstructures are fully developed. Therefore, the composition and functional structure of the Old Town need to be developed further, adding new cells. This feature of its is an objective basis for creativity in the Old Town to flourish" [3]. One can agree with the researcher that the Vilnius Old Town has internal resources and potential for further development, but it should be noted that the creation of new urban quality in the historical environment, without compromising the existing harmony, is a complex and complicated task. Its solution requires methodological consistency. In order to achieve the final result, the projects should consistently pass the stages of the study of the peculiarities of the existing urban structure, the substantiation of the concept and preparation of detailed designs. The success of projects also depends on the mastery of the developers.

In the 21st century, investors have been particularly active in their initiatives to develop various projects and initiate new construction in the Old Town of Vilnius. Such initiatives are strictly regulated by the Lithuanian state heritage protection institutions and are frequently resisted by the society. The research work presented in the article analyses the possibilities of the emergence of namely new buildings in the eastern part of the Old Town of Vilnius, in the territory of the historical suburb behind the Subačiaus gate of the former defensive wall, at the approaches to Subačiaus street. Various designing works have been going on in this area since 2007. 
Development of the eastern territory of the Old Town of Vilnius and the established values

\section{Old Town of Vilnius}

Vilnius, as the capital of the state of Lithuania, was for the first time mentioned in a written source in 1323 , when the state was ruled by grand duke Gediminas. Today the town's historical centre consists of: (i) the territory of castles; (ii) the historical kernel of the town, which was surrounded by a defence wall in the 16th century; and (iii) historical suburbs that formed by the mid 19th century (Medieval suburbs). Historical buildings represent various architectural styles. Nearly $40 \%$ of these buildings are of the highest architectural and historical value. Together they form a very rich, multifaceted and, at the same time, harmonious townscape. The plan and spatial structure of the old Vilnius is a good example of a naturally developed organism of a town, with all the development traces preserved and clearly visible. No major urban changes were undertaken in this town until the second quarter of the 19th century. The town's plan developed spontaneously, its structure was mainly determined by the roads and topographic conditions - Vilnius Old Town has a typical medieval street network structure. From the 13 th century until the middle of the 18th century Vilnius Old Town had a strong influence on architectural and artistic developments of the entire region (Lithuania, Belarus, the Ukraine and Poland) and is the most East remote town of Central Europe, in which a strong interaction of the cultures of Eastern and Western Europe took place. In 1994 the historical centre of Vilnius was included in the World Heritage List - it is thus recognised as having an outstanding universal value from the point of view of history, art, science, aesthetics, ethnology and anthropology and is classified as a living, developing and changing town [4].

Vilnius has more than one historical suburb. The unique feature of this town is that the town's kernel and the suburbs located closest to it have coalesced into one unit - sometimes it is even not clear where the border separating them goes. It is more visible only where natural barriers still exist today. Despite these natural barriers the suburbs blend smoothly into the town's pattern. In many cases these borders link rather than separate the town's individual parts. The plan structure and the composition of the population of the suburbs have made them different from the town itself and from each other [5].
Eastern part of the Old Town of Vilnius. Ensembles of the Missionary Monastery and the Children's Shelter of Baby Jesus

The literature about Vilnius mentions the suburb behind the Subačiaus gate as one of the oldest inhabited places in Vilnius. The formation of this suburb could have been affected by the road to Polotsk and construction of the Bishops' Mill at the end of the 14th century. The territory gained more inhabitants in the 15 th -16 th centuries. At the end of the 16th century and at the beginning of the 17th century, the territory had craftsmen's wooden houses, the formation of estates and built-up in this place depended on the city's defensive wall and the complicated conditions of natural environment (land pocket, hill, steep slope). In the first half of the 17th century, several of the buildings and plots in the area went to the Lithuanian noblemen family of dukes Sanguškos. A palace was built in the territory. At the end of the same century, the estate passed to the ownership of the Missionary Monastery. The monks significantly expanded their territory at the expense of the surrounding craftsmen's plots. In 1695-1730, the missionaries built the Church of the Lord's Ascension, built a monastery and utility buildings near the former Sanguškos Palace, thus forming the ensemble of the Missionary Monastery buildings by the present Subačiaus street. In the 18th century and in the first half of the 19th century, the monastery became a major center of religion, culture and education. By fostering charity ideas, at the end of the 18th century, the missionaries, together with influential sponsors, founded the Children's Shelter of Baby Jesus next to the monastery, which was taken care of by nuns sisters of mercy. A two-storey masonry house was built as the shelter building. At the beginning of the 19th century, the territory of the shelter was expanded at the expense of the city land areas, incorporating the current territory of the Basteja (artillery fortifications) and a private estate by the Vilnia river. The primary function of the Children's Shelter of Baby Jesus also remained after World War II - it was the Infant Home. On 1976-1978, the building was reconstructed, a new annex was connected to it and it became a part of the Second Vilnius City Hospital, called the Missionary Hospital. During the construction of a new block of the hospital, the northern wing of the Children's Shelter of Baby Jesus was demolished [6]. 


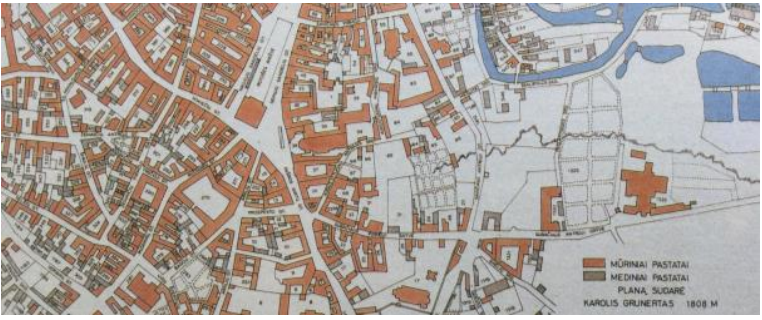

1808

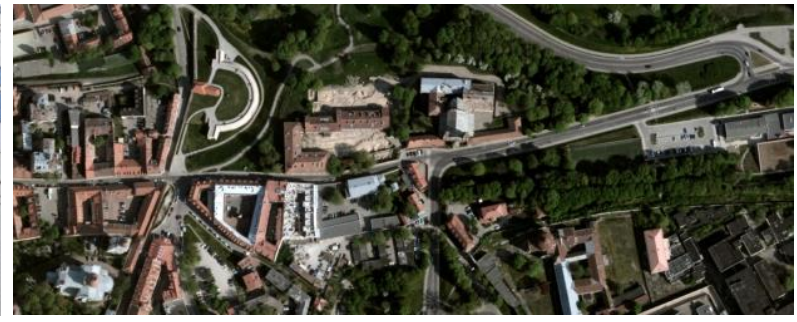

2017

Fig. 1. Fragments of the Maps of Vilnius Old Town.

Photo in 1808: [7], photo in 2017: http://www.maps.lt/map/default.aspx?lang=lt\#q=Vilnius.

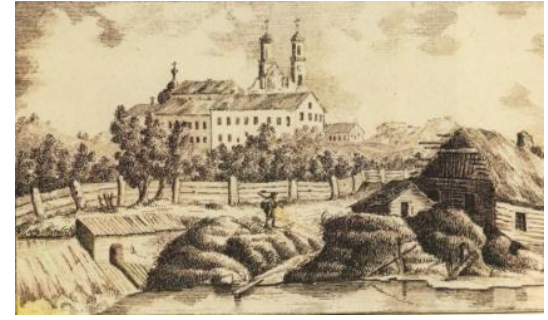

1833

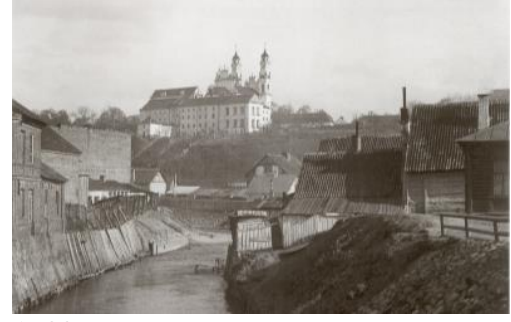

1900

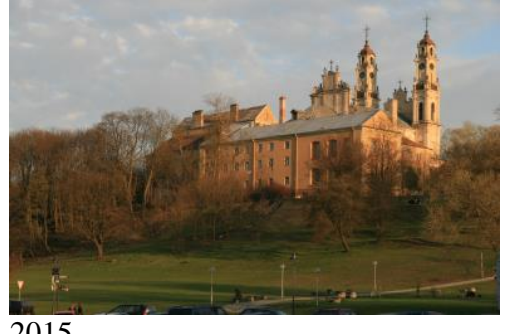

2015

Fig. 2. The Ensemble of Missionary Monastery. Photo in 1833:[7], in 1900: [8], in 2015: photo by the author.

The volumetric spatial composition of the Missionary Monastery ensemble has remained almost unchanged up to this day. This is an original and dynamic composition of the buildings of different volumes with the dominant double-tower church (Fig. 1, 2). The former built-up by Subačiaus street, between the Missionary Monastery ensemble and the Children's Shelter of Baby Jesus became obsolete.

\section{Values and regulation of urban development of the formed territory}

In 2007, in the territory in question, i.e. at approaches to Subačiaus street, the Vilnius City Municipality sold four buildings of the former hospital by way of a public auction. For more than ten years, various development projects have been prepared for this territory. Finally, an architectural competition was held in 2014, the project selected during which should be implemented. The research work presented in the article assessed all researches performed in 2007-2018 and valid legal documents, which helped to define the relevant tasks and scopes of the urban research.

Based on archaeological research, the area under consideration was built up with wooden buildings already in the 16th century, from the middle of the 17 th century masonry buildings were also erected here (the remains of three masonry buildings were uncovered), although some of the buildings remained wooden (the remains of a wooden building and basement with stone-based floors were found), masonry buildings were also built in this area in the 19th century, household and construction ceramics production site dating back to the end of the 16th century and the 1 st half of the 17 th century were found here. However, the condition of the remains of the uncovered furnaces and the masonry buildings of the 17th century and 19th century is very poor, the excavated masonry work is deteriorating. Only the eastern masonry wall of the northern block of the Children's Shelter of Baby Jesus has survived well and is strong, which archaeologists recommend to preserve $[9 ; 10 ; 11]$.

According to the historical study of the complex of buildings of the former Missionary Hospital, the exploratory architectural studies and the special plan for the protection of the immovable cultural heritage of the ensemble of the Monastery buildings (hereinafter referred to as the Special Plan), one can identify the main characteristics and the formed values of the territory and architectural ensembles:

- The land plots of the complex of the Missionary Monastery and the church and of the Children's Shelter of Baby Jesus were historically and functionally independent and two separate architectural ensembles were formed.

- The area between the complex of the Missionary Monastery and the church and of the Children's Shelter of Baby Jesus was built up in the 18th century; at the beginning of the 19th century it was turned into a garden that originally belonged to the monastery, later to the Children's Shelter of Baby Jesus.

- The natural boundary between the complex of the Missionary Monastery and the church and of the Children's Shelter of Baby Jesus is a noname dead-end street as the extension of Rasu street, that has existed since the 18th century.

- The northern part of the building of the Children's Shelter of Baby Jesus was demolished in 1976, when building the hospital.

- In the urban heritage protection aspect, the builtup in the land plot of the Children's Shelter of 


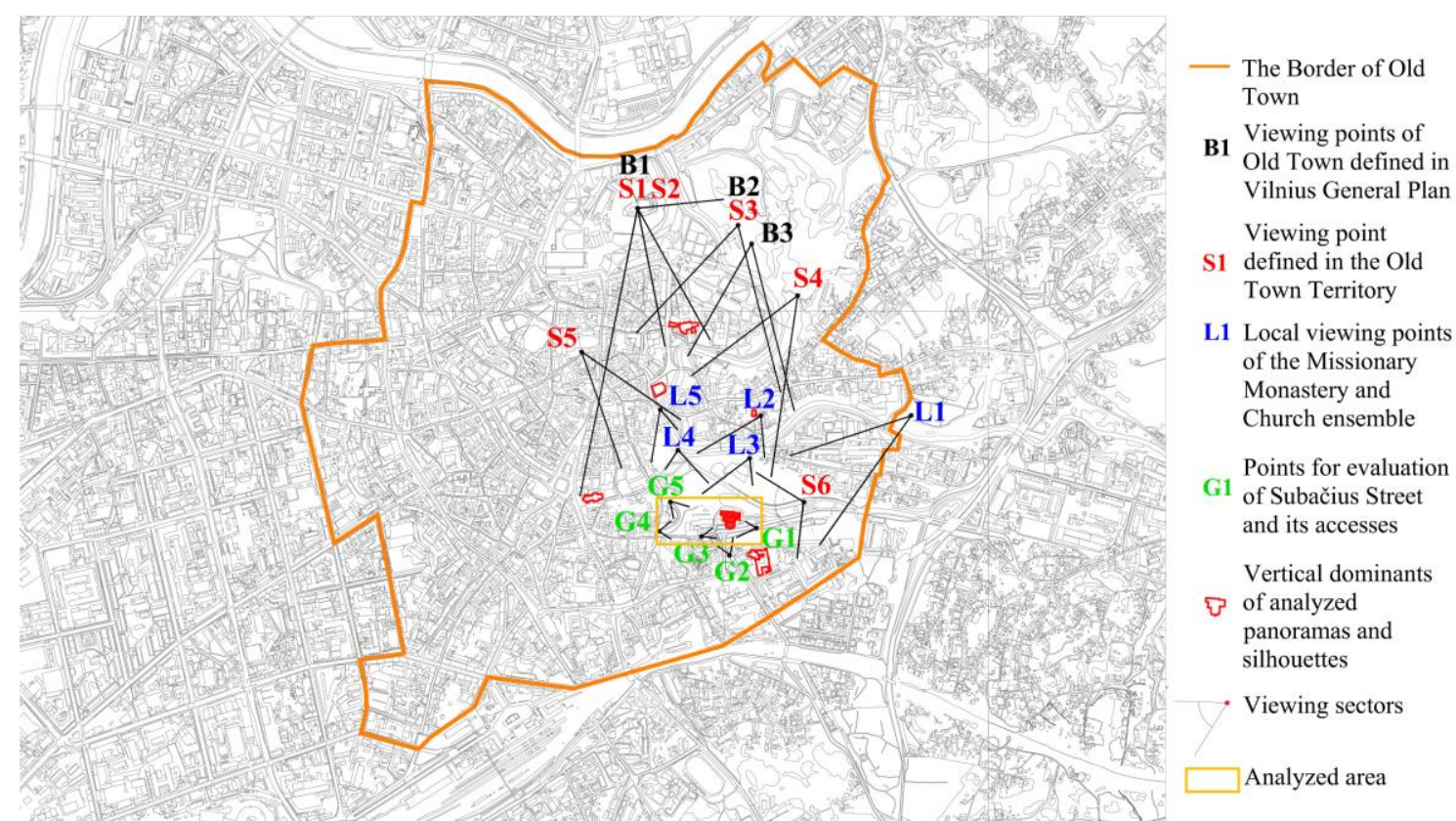

Fig. 3. Viewing Points and Places from which the Situation was Acsessed. Scheme by the author, 2016, 19.

Baby Jesus is not formed: the northern part of the building of the Children's Shelter of Baby Jesus is demolished; the Children's Hospital building violates the object of heritage, does not have architectural value; after the buildings by Subačiaus street were demolished, the character of the street built-up structure has changed non-typically.

- The ensemble of the Missionary Monastery and the church is one of the most important voluminous-spatial dominant elements of the Old Town of Vilnius.

- In the panoramic views, the buildings of the Children's Shelter of Baby Jesus and the hospital visually blend with the built-up of Subačiaus street.

- The Missionary Monastery and church ensemble and buildings of the Children's Shelter of Baby Jesus organically extend the built-up of the Old Town, emphasizing the historical tract Subačiaus street.

- The green slopes of the former monastery garden are a visual part and parcel of the ensemble.

- The Missionary Monastery and church ensemble and the Children's Shelter of Baby Jesus can be seen from the most important viewing points in the Old Town of Vilnius and many places in the eastern part of the Old Town. Also, this territory is one of the most perfect viewing points in the Old Town of Vilnius $[6 ; 12 ; 13]$.

The Special Plan has established priority management directions for the area in question:

- The priority direction in the management of the territory of the ensemble of the Missionary
- Monastery buildings is the preservation of the urban structure.

- Meanwhile, in case of the territory of the Children's Shelter of Baby Jesus building, the priority direction is regulated transformation of the urban structure in order to restore the destroyed historical urban spatial structure or extend the principles of spatial formation characteristic of the Old Town of Vilnius [14].

The main goal of the regulated transformation of the urban structure (according to the concept of the Special Plan of the Old Town of Vilnius) is "to preserve all the attributes of authenticity, restore the lost physical and technical qualities, to highlight and reveal the cultural value and adapt to the needs of the present. In the parts of the territory, where the built-up structure has lost the signs of authenticity, the management construction works can be performed (construction or demolition works, as defined in the Law on Construction), construction of new buildings (conversion) is regulated in compliance with the features of the integrity (morphology) of the territory built-up. The transformation of the built-up structure is regulated, in order to restore the destroyed urban spatial structure or to extend the principles of spatial formation typical of the Old Town of Vilnius, one may be guided by the resolutions of the Government of the Republic of Lithuania, other legal acts and approved and effective territory planning documents" [15].

The Special Plan establishes the following main goals for the territory of the Children's Shelter of Baby Jesus building in the historical urban aspect: 


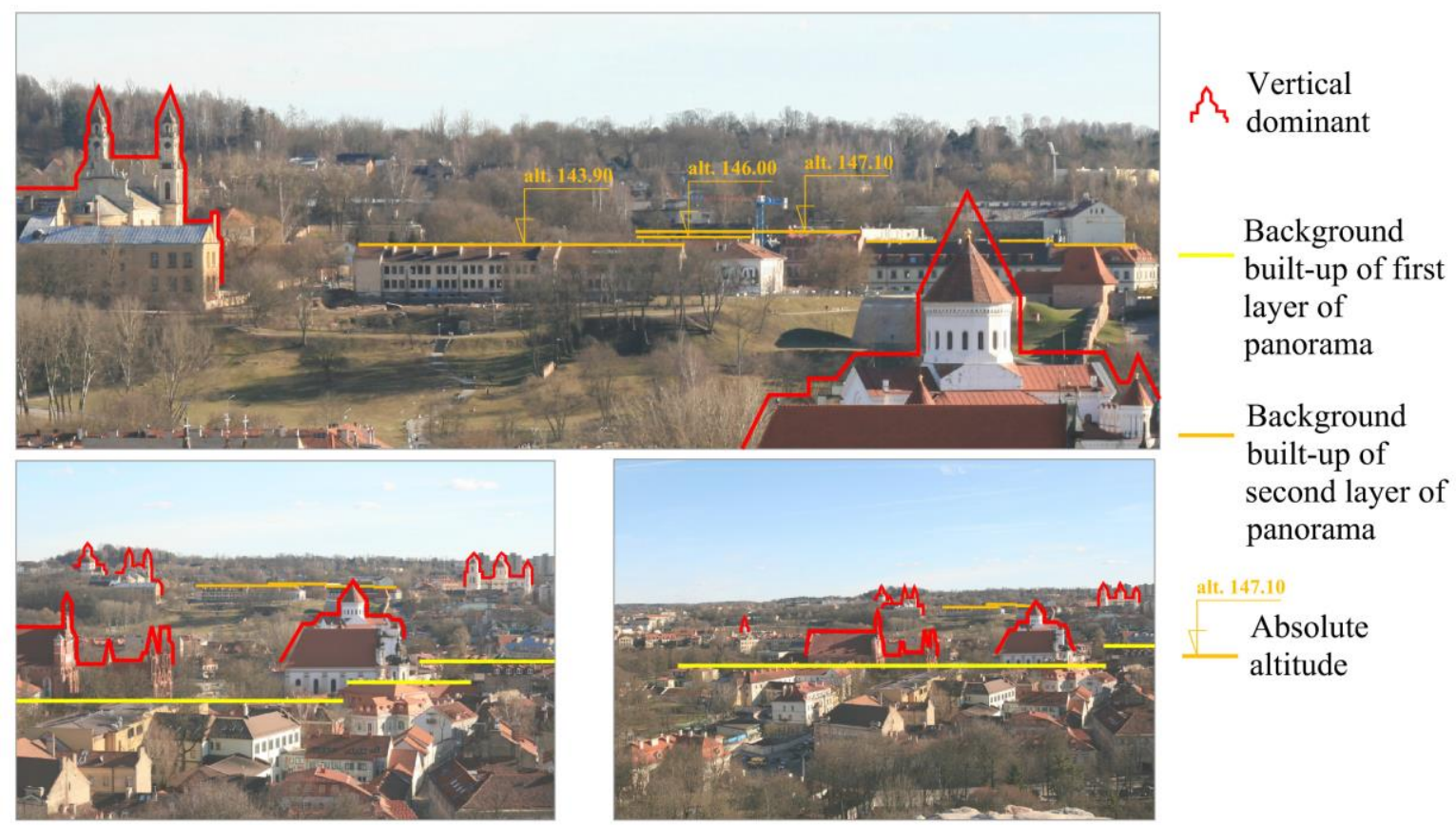

Fig. 4. Analysis of the Panoramas. Viewing Points S1, S2, B1. Photos and analysis by the author, 2016, 19.

- The reconstruction of the hospital block built in the post-war years (at the time of the construction, a part of the Children's Shelter of Baby Jesus building was demolished), adapting it to the restored building of the Children's Shelter of Baby Jesus, bringing it to better harmony with the silhouette of the ensemble of Missionary Monastery buildings and forming the built-up morphotype typical of the Old Town;

- Highlighting the features of the typical Subačiaus street built-up by restoring or shaping with new buildings the characteristic urban structure and layout [14].

The Special Plan establishes the allowed built-up density, intensity, height of buildings for this territory. The height of buildings by Subačiaus street in restoring built-up should be determined by research.

According to the data of the Cultural Heritage Register, valuable features were assigned to the ensemble of the Missionary Monastery buildings (unique code 761) by Act No. KPD-AV-380 of the Immovable Cultural Heritage Evaluation Council of the Cultural Heritage Department, dated 5 November 2012. Valuable features of the Children's Shelter of Baby Jesus building were established by Act No. VI-RM-160 of the Immovable Cultural Heritage Evaluation Council of the Vilnius City Municipality, dated 23 April 2010. Valuable features of these ensembles established in the acts define the valuable qualities of the volumes of the buildings, the layout, the architectural solution of the facade, the structures, and the materials. The definition of volumes is relevant for the urban research, but for the formulation of the task of the urban research, the valuable features of the Old Town of Vilnius (unique code 16073), as an urban area, which includes the approaches to Subačiaus street in question, are more important. For the research of the approaches to Subačiaus street, the following features are relevant: routes of historical streets; natural elements (relief, slopes of the Vilnia valley terraces); built-up features; open urban spaces; panoramas and panoramic viewing points; silhouettes; perspectives; dominant elements [16].

The restoration of the valuable historicallydeveloped built-up is based on historical urban development studies based on analysis of historical sources and iconographic material, as well as archaeological research. Based on such studies of the approaches to Subačiaus street, one may conclude that from the urban point of view it is the Missionary Monastery and church ensemble and the Children's Shelter of Baby Jesus buildings that are valuable. In the remaining area between these buildings, there were no valuable urban structures developed and there are no valuable buildings that could be restored. The priority directions of the management of the territory of the Children's Shelter of Baby Jesus building provided for in the Special Plan allow and recommend the regulated transformation of the urban structure in order to restore the destroyed historical urban spatial structure or extend the principles of spacial formation, which are characteristic of the Old Town of Vilnius. When restoration is not an option, only regulated new construction can be performed. A lot of parameters for new construction are already 
given in the very Special Plan: built-up density, built-up intensity, recommended typical built-up morphotype. The main task of the urban research is to answer the question about the possible height and location of the new built-up at the approaches to Subačiaus street. The research work chooses the following urban research methodology - natural urban research of the current situation, assessing the possible visual impact of the new built-up on the established valuable features of the Old Town of Vilnius and individual objects (the monastery complex, the shelter).

\section{Assessment of possible visual impact of the new built-up}

The visual identity of the townscape of the Old Town of Vilnius is perceived from the external Old Town viewing points and internal characteristic viewing points. The master plan of the city of Vilnius and the act of establishing valuable features of the Old Town respect the uniqueness and value of the city silhouette and panoramas, indicating points the view from which should not radically change. This method is fairly widespread for cities with clear silhouette viewing sites. When a city has a clearlydefined relief and its historic dominant elements are dispersed (as in case of Vilnius), then the application of the so-called "viewing points" method may be insufficient. Then, the viewing conditions must be evaluated more precisely and divided into points of panoramic views and points of mass observation (low-situated crowding places - streets, bridges, squares, recreational areas, etc.). The visual viewing zone of the Old Town of Vilnius is located in the form of two rings. The first narrow ring surrounds the Old Town, and the viewing points are located on the hills that rise 20-70 metres above the city. The second ring consists of separate viewing points on the hills at a distance of $2-3 \mathrm{~km}$ from the Old Town, from where it is seen as a small-scale silhouette [17].

The need for height regulation relates to the valuable peculiarities of the urban structure. In the case of the Old Town of Vilnius, the built-up can be considered as a historically present and very valuable environment, therefore the built-up height is fixed as final.

The panoramas and silhouettes of the Old Town of Vilnius have features characteristic of a city that developed spontaneously and uninterruptedly: the organic connection between nature and architecture, the interconnection of verticals different in volume and shape with ordinary buildings, quite a lot of randomness and chaos. But in this "aesthetic mess", the regularity of the vertical arrangement in three groups is clearly noticeable. The groups capture the former most important places in the city. The concentration of verticals in groups gives the silhouette a wave that repeats itself on a hilly relief $[3,18]$.

Assessing the potential impact on the panoramas, silhouettes and dominant elements of the Old Town of Vilnius, two categories of viewing points and places from which the situation was assessed are distinguished:

1. The viewing points of the Old Town important on the city scale (the Old Town viewing control points and other important Old Town viewing points captured in the master plan of the Vilnius city municipality).

2. Regulated viewing points in the Old Town territory (the panoramic view points and silhouette observation locations indicated in the act of the Vilnius Old Town Evaluation Council).

Since the townscape is characterized not only by its external but also internal characteristics; therefore, in choosing the viewing points, it was necessary to evaluate not only the quality of the static image but also the changing view while moving. The aim of an "ideal" view from any possible viewing point is an unrealistic task, therefore, priority viewing points and routes were selected in this work, which allowed to assess the possible visual impact of new built-up on local spaces and nominal pictures of Subačiaus street. Characteristic observation locations of nominal spaces and nominal picture were also of two categories:

1. Local points of viewing the Missionary Monastery and church ensemble.

2. Locations of assessing Subačiaus street space and its approaches (Fig. 3).

\section{An assessment of the visual impact on the townscape of the Old Town of Vilnius}

The analysis of the panoramas of the Old Town important on the city scale has revealed the following characteristic features:

- Panoramic view is multidimensional.

- Both the first and the second layer of panorama distinguish vertical dominant elements (church and monastery ensembles) and the background built-up of the Old Town (mostly residential buildings).

- From some hills, the array of trees forms the first layer of panorama.

- The built-up at approaches to Subačiaus street is background built-up of the second layer of panorama. The altitude of the buildings rooftops ranges from 143.90 to 147.10 of the absolute altitude (Fig. 4).

In the fragment of panorama from the viewing point located inside the Old Town (the bell tower of St. Johns' Church), covering the approaches to Subačiaus street, the background built-up of the second layer of panorama is covered by an array of trees and the very built-up is visible fragmentarily (Fig. 5). 

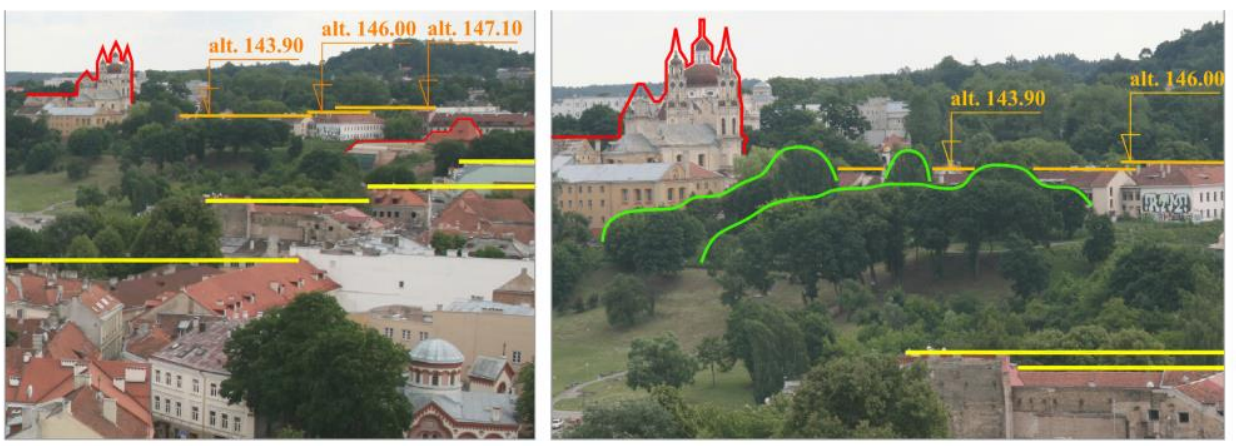

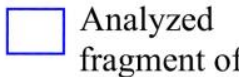
panorama

Vertical dominant

Background built-up of first layer of panorama

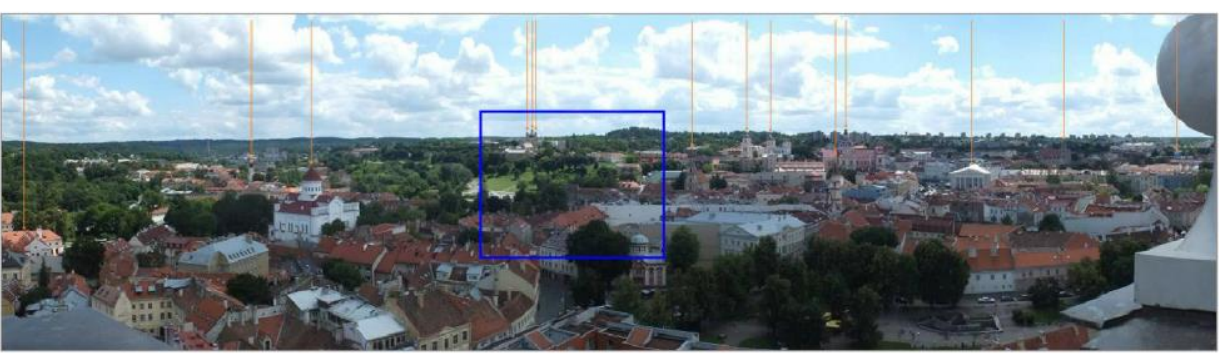
Background built-up of second layer of panorama alt. 147.10

- Absolute altitude $\neg$ Mass of trees

Fig. 5. Analysis of the Panoramas. Viewing Point S5. Photos and analysis by the author, 2016, 19.
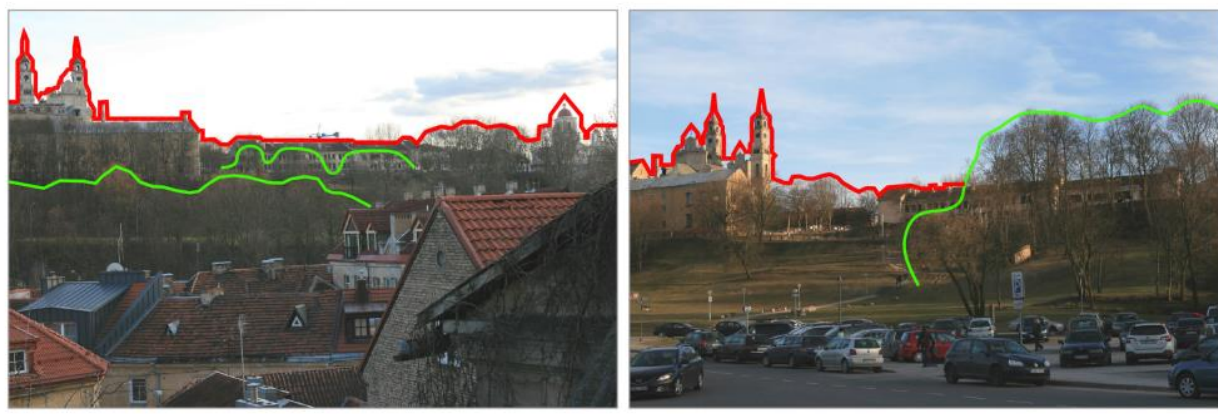

$\Omega$ Line of silhouette

$\neg$ Mass of trees

Fig. 6. Analysis of Silhouette. Viewing Points L2, L5. Photos and analysis by the author, 2016, 19.
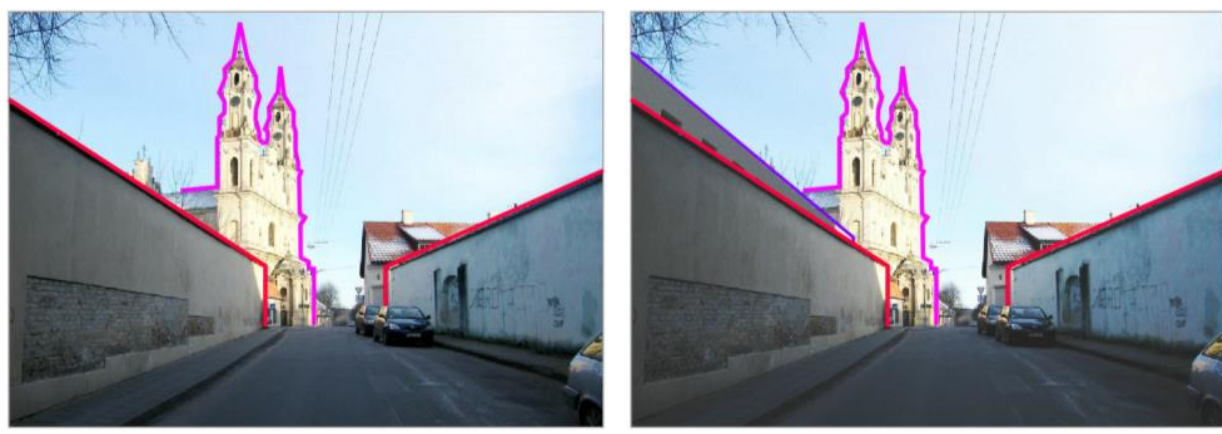

Dominant of street's perspective view First layer of street's perspective Second layer of street's perspective

Fig. 7. Perspective View of Subačiaus Street. Viewing Point G3. Photos and analysis by the author, 2016, 19.
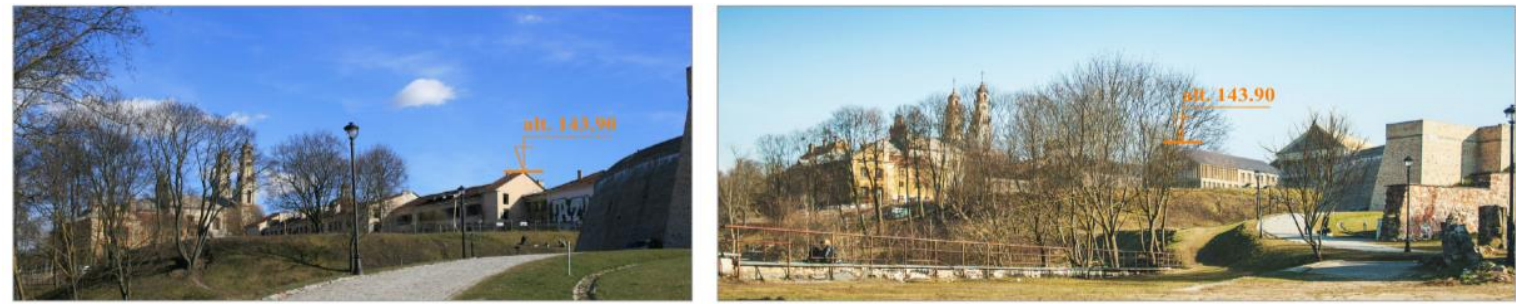

B

Fig. 8. Silhouette of Subačiaus Street. Viewing Point G5 (A - The Former Hospital, B - Newly Formed Built-up). Photo and visualization by DO Architects, 2016. 
The fragment of the southeast silhouette from Subačiaus street captured in the act of the Vilnius Old Town Evaluation Council, encompassing the territory in question, is dominated by the Missionary Monastery and church ensemble and the array of trees. Newly formed built-up in approaches to Subačiaus street is not visible.

Analyzing the panoramas of the Old Town from the individual viewing points on the hills at a distance of $2-3 \mathrm{~km}$ from the Old Town, the virtual panoramas of the GIS modelling were evaluated. In these panoramas the Old Town is seen as a smallscale silhouette, while the background built-up of approaches to Subačiaus street either is not visible at all or it merges with the arrays of trees behind it.

\section{An assessment of the visual impact on local spaces} and nominal pictures of Subačiaus street

Analyzing the local points of viewing the Missionary Monastery and church ensemble and the newly developed built-up in Subačiaus street, the built-up is projected as a silhouette against the sky. The following features of the silhouette appear:

1. The array of trees plays a prominent role in silhouettes, many of which cover the background built-up (Fig. 6).

2. Silhouettes show fragments of three blocks being newly designed instead of the current hospital building and the Children's Shelter of Baby Jesus building.

3. A new building beign designed in parallel to Subačiaus street is not visible in silhouettes.

In order to evaluate the possible impact of the new built-up in approaches to Subačiaus street on the characteristics of the Subačiaus street space itself, the characteristics of this street need to be described. The classical division of urban spaces into types is as follows: (1) street-type space; (2) embankment-type space; (3) the transitional type of space between a street and a square; (4) square-type space. Subačiaus street begins in the territory of the Old Town kernel, formerly circled with the defensive wall, and extends beyond the defensive wall to the former historical suburb. The street-type and embankment-type spaces interchange there. We are interested in the section of Subačiaus street behind the former defensive wall. This section begins with an embankment-type space - it has buildings only one (southern) side. The absence of buildings on the northern side opens up a view to Basteja and the Old Town panoramas. The street-type space begins from the Children's Shelter of Baby Jesus and buildings at Subačiaus st. 19 and goes towards the Missionary Monastery and church ensemble. The ratio of the width and height of space in this section is equal to one, the perspective is deep (as there are no abrupt street turns), the space ends with the Missionary
Monastery and church ensemble. Another vivid and exceptional feature of the street space section is that the street perimeter is formed not only with buildings and also with high masonry fences that mark boundaries of the estates. According to V. Jurkštas, such a composition of street space is considered to be the most vivid stereotype of Vilnius. "... this feature of space and architecture is typical of the cities of such social society that lived private family life. It can be said that exclusiveness of street space and architecture is a sign of an archaic city. It is only in a rare European city that the archaic form remains, therefore, such Vilnius streets should be particularly well protected [3]".

The assessment of the influence of built-up restored and newly formed at the approaches to Subačiaus street on the spatial characteristics of Subačiaus street has revealed:

1. The first layer of panorama of the perspective view of Subačiaus street from the east is formed by the ensemble of the Church of the Lord's Ascension (Missionary Church) and a masonry fence. Newly designed buildings form the second layer of panorama, they do not exceed the height of the background built-up at Subačiaus street.

2. The first layer of panorama of the perspective view of Subačiaus street from the west is formed by masonry fences and the perspective is crowned and closed by the ensemble of the Church of the Lord's Ascension (Missionary Church). The newly designed building, which is set back from the fence and is parallel to the Subačiaus street, affects the perspective view, but does not change its essential characteristics (Fig. 7).

3. The built-up being restored and newly formed complements and provides multiplicity to the currently poor Subačiaus street perspective view from the north.

4. The built-up being restored and newly formed does not affect the silhouette observed from the crossing of Bokšto and Subačiaus streets.

5. The built-up being restored and newly formed tranforms the silhouette that is currently formed by the abandoned building of the former hospital, but the altitude of the rooftops of the buildings forming the silhouette does not change (Fig. 8).

\section{Conclusions}

Summarizing the research done, it is possible to draw conclusions both about the specific case of the Old Town of Vilnius and about the general evaluations of the transformation potential of urbanised landscape and its methods.

The Vilnius case study revealed: 
1. The built-up of the Old Town of Vilnius and its fragments can be considered as a historically present and very valuable environment, therefore the built-up height is fixed as final.

2. The master plan of the city of Vilnius and the act of establishing valuable features of the Old Town respect the uniqueness and value of the city silhouette and panoramas, indicating points the view from which should not radically change.

3. If the newly formed built-up in the approaches to Subačiaus street does not exceed the highest altitude of buildings in the background built-up of Subačiaus street, it will not affect the formed valuable panoramas and silhouettes of the Old Town of Vilnius

General conclusions: Many of the old towns formed as valuable urbanised landscapes. However, the transformation of urban structures of viable cities, which also entails transformation of urbanised landscapes, is inevitable. Basically, there are only two ways of transformation - either it happens in its own way or it can be professionally controlled.

In order to evaluate the possible impact of the urbanised landscape transformation on the formed townscape values, complex urban studies are needed that would justify one or another parameter of the emerging built-up (height, built-up intensity, morphological type of built-up, etc.). Such studies are unique in each case, since for each situation, depending on the parameters studied, an individual research methodology should be developed. After carrying out natural studies, considering the urban architectural peculiarities, volumetric-spatial modeling (parameters of the building, approaches to it) should be performed and the potential impact of the new built-up on the urban context should be assessed.

\section{References}

1. Vienna Memorandum on "World Heritage and Contemporary Architecture - Managing the Historic Urban Landscape” [online 10.07.2018]. https://whc.unesco.org/en/documents/5965

2. Feilden, B. M., Jokilehto, J. Management Guidelines for World Cultural Heritage Sites. Rome, ICCROM, 1998. 140 p. [online 10.07.2018]. https://www.iccrom.org/sites/default/files/2018-02/1998_feilden_management _guidelines_eng_70071_light_0.pdf

3. Jurkštas, V. Vilniaus senamiesčio tūrinè-erdvinè kompozicija. Architektūros paminklai, 1977, vol. 4, p. 36-120.

4. Dijokienè, D. The impact of historical suburbs on the structural development of cities (based on examples of European cities). Urban heritage: research, interpretation, education / Vilnius Gediminas Technical University. Faculty of Architecture, Department of Cultural Heritage under the Ministry of Culture of Lithuania. Vilnius: Technika, 2007, p. 141-145.

5. Dijokienė, D. Urbanistinis istoriniu priemiesčiu paveldas. Urban Heritage of Historical Suburbs. Vilnius: Technika, 2009. $216 \mathrm{p}$.

6. Vileikienè, L. Buv. Misionieriu ligoninès pastatu komplekso istorine apybraiža, 2008 [research report].

7. Drèma, V. Dingęs Vilnius / Lost Vilnius. Vilnius: Vaga, 1991, p. 43.250 p.

8. Fleury, S. F. Fotografijos / Photographs. Vilnius: Lietuvos nacionalinis muziejus, 2007. 315 p.

9. Poška, T. Žvalgomieji archeologiniai tyrinejjimai, 2008 [research report].

10. Šiaulinskas, R. Žvalgomieji archeologiniai tyrimai, 2013 [research report]

11. Stankevičiūtė, J. Detalieji archeologiniai tyrimai, 2015 [research report].

12. Valeckas, R. Žvalgybiniai architektūriniai tyrimai, 2018 [research report].

13. Zilinskas, R. Papildomi architektūros tyrimai, 2015 [research report].

14. Vienuolyno statiniu ansamblio (u.k. 761) Subačiaus g. 24, 26, 28 Vilniuje, nekilnojamojo kultūros paveldo apsaugos specialusis planas, patvirtintas LR Kultūros ministro 2015-08-31 isakymu Nr. IV-558, 2015. [online 01.07.2018]. http://www.kpd.lt/uploads/Specialieji\%20planai/Koncepcijos/761/Microsoft\%20Word\%20\%20AISK_\%20SPREND_K_2015-06-15.pdf

15. Vilniaus senamiesčio regeneravimo projekto koncepcija ir sklypu planas, patvirtintas Vilniaus miesto valdybos 1995 03-23 sprendimu $\mathrm{Nr} .775 \mathrm{~V}, 1995$.

16. Nekilnojamojo kultūros paveldo vertinimo tarybų aktai, nustatantys vertingąsias savybes (Kultūros vertybių registro duomenys): Vaikelio Jézaus prieglaudos pastato (u.k. 33915), Vilniaus misionieriu vienuolyno statiniu ansamblio (u.k. 761), Vilniaus senamiesčio (u k. 16073) ir Vilniaus senojo miesto vietos su priemiesčiais (u.k. 25504). [online 22.06.2018]. https://kvr.kpd.lt/\#/static-heritage-search

17. Daunora, Z. J., Kirvaitienė, S., Vyšniūnas, A. Vilniaus miesto vizualinio identiteto apsauga ir plètros principai. Vilnius: Technika, 2004. 145 p.

18. Jurkštas, V. Senamiesčiu regeneracija. Architektūros harmonizavimo problema. Vilnius: Technika, 1994. 159 p.

19. Dijokienè, D. Atkuriamo ir naujai formuojamo užstatymo principu tyrimas subačiaus g., Vilniaus senamiestyje, 2016 [research report]. 
INFORMATION ABOUT THE AUTHOR:

Dalia Dijokienè - obtained B. arch. and M. Sc. arch. from Vilnius Gediminas Technical University in 1995 and 1997 respectively. She received the degree of Doctor of Humanities in Architecture from VGTU in 2002. The theme of her PhD thesis was Historical Suburbs: Genesis, Development, Value, Maintenance (on the Example of Lithuanian Towns). Since 2004 she has been an Associate Professor at the Department of Urban Design, Faculty of Architecture, Vilnius Gediminas Technical University and since 2013 - Head of the Department of Urban Design. In 2006-2018 she has been a guest lecturer at the Universities in Italy, Poland, Norway, the Netherlands, Slovenia. In 1999 she was an architect trainee at Lyngby, Denmark. From 1998-2007 she was an Architect with Closed Joint Stock Company "Atkirta UAB". Since 2007 she is a freelance architect. She is the author and co-author of more than 30 architectural projects. She is the author of 24 scientific publications and has presented reports at 22 international and national conferences. Contact data: Department of Urban Design, Faculty of Architecture, Vilnius Gediminas Technical University, Traku Str. 1, 01132, Vilnius, Lithuania. E-mail: dalia.dijokiene@vgtu.lt

Kopsavilkums. Raksts analizē vērtīgu urbanizēto ainavu transformācijas potenciāla novērtējumu. Daudzas vecpilsētas ir veidojušās, kā nozīmīgas urbānās ainavas. Urbāno struktūru transformācijas dažādās pilsētās ir nenovēršamas. Pamatā ir divi transformācijas veidi: tas notiek pats savā veidā, vai kontrolēti. Raksts atspoguḷo transformācijas problemātiku, kas ilustrēta ar Viḷnas vecpilsētas austrumu daḷas (UNESCO mantojuma teritorija) analītisko izpēti. Viḷnas vecpilsētas austrumu daḷā atrodas divi arhitektūras ansambḷi, kas veido raksturīgo pilsētas siluetu. Kopš 2007. gada ir vairākas jaunas būvniecības aktivitātes uzsākušās šajā pilsētas daḷā. Rakstā izvērsta diskusija par pētījumu, kas tika veikts ar mērki noteikt apbūves augstumu jaunceltnēm vēsturiskajā Viḷnas priekšpilsētā. Potenciālā jaunbūvju ietekme uz panorāmu, siluetu, dominantēm un perspektīvu, kā arī esošo telpu konkrētajām ielām vēsturiskajā priekšpilsētā. Raksts atspoguḷo urbanizētās ainavas vizuālās ietekmes noteikšanas metodi. 